Przegląd Prawa Konstytucyjnego

------ISSN 2082-1212-------

DOI 10.15804/ppk.2016.06.11

$-\mathrm{Nr} 6(34) / 2016$

\title{
Marian Grzybowski
}

\section{Ownership Right - Private vs. Public Aspect}

Keywords: ownership substace, constitutional freedoms and rights, public law, private law, ownership (property), community coexistence, exclusiveness of exploration, expropiation

Słowa kluczowe: istota własności, konstytucyjne wolności i prawa, prawo publiczne, prawo prywatne, własność, współżycie społeczne, wyłączność korzystania, wywłaszczenie

\section{Summary}

Ownership is considered, predominatly, to be a legal notion. But it has also some conotations in the frame of economics, philosophy and sociology. In the doctrine of law there were framed numerous and slightly different definitions of ownership. Most of them, however, emphasise the dominant role of the owner's unlimited and exclusive power over a thing (or value) as well as his (her) dominat role to explore possibilities of legal and factual disposal.

The Constitution of Poland of 1997 deals with the ownership (property) rights twice: in article 21 (within the basic constitutional regulations) and, even more detaily, in article 64 (1-3), in Chapter II of the Constitution, dealing with the civil fredoms and rights of entity. The central issue under the author's consideration should be framed in a question: to which extend the limitations pointed in article 31(3) of the Constitution may define exploration of the owner's rights and powers protected by the Constitution, in particular; by its provisions framed in its articles 21 and 64 ?

1 The author is a professor in the Departament of Comparative Constitutional Law the Faculty of Law and Administration of Jagiellonian University in Krakow. E-mail: marian. grzybowski@uj.edu.pl. 


\section{Streszczenie}

\section{Własność jako prawo - aspekt prywatny w zestawieniu z publicznym}

Własność funkcjonuje jako pojęcie prawne. Posiada nadto określone konotacje w sferze ekonomii, w filozofii i socjologii. W doktrynie prawnej podjęto szereg prób definiowania własności. Wszystkie be mała ujęcia akcentują, obok zróżnicowań, wyłączność właściciela w korzystaniu z rzeczy lub wartości stanowiących przedmiot własności ora z dysponowania nimi.

Konstytucja RP z 1997 r. odnosi się do własności w art. 21 (w grupie unormowań wyznaczających zasady ustroju państwa) oraz w art. 64 ust. 1-3 (w rozdziale II, odnoszącym się do wolności, praw i obowiązków człowieka i obywatela). Autor rozważa w pracy kwestię: czy i w jakim zakresie na możliwość korzystania r rzeczy (wartości niematerialnej) przez właściciela rzutują ograniczenia w korzystaniu z wolności i praw konstytucyjnych, przewidziane w art. 31 ust. 3 Konstytucji RP?

\section{I.}

In legal discourse, both in the past and nowadays, ownership is considered to be such a notion, and a legal institution at the same time, towards which a broad spectrum of views is presented, as well as differing definitions are proposed. It is both a legal and economic notion, and what's more - subject of interest of philosophy and sociology ${ }^{2}$. According to J. Bentham, the idea of property right comes down to expectation that an owner (owners) is entitled to take benefits from their property, where this expectation is sanctioned by the system of legal norms in force; it becomes therefore 'the creature of law'3.

2 K. Lorenz, M. Volf, Allgemeiner Teil des bürgerlichenRechts, $9^{\text {th }}$ edition, München 2004, pp. 251-252; J. Lehmann, Schherschaft und Socialbindung, Berlin 2004, pp. 39-40, W. Pańko, Własność jako kategoria ekonomiczna a prawo własności, 'Acta Universitatis Wratislaviensis', No. 609, Prawo, Wrocław 1983, pp. 153-155; M. Kaczmarczyk, Wstęp do socjologicznej teorii własności, Warszawa 2006, pp. 186-187; G. Radbruch, Filozofia prawa, Warszawa 2009, pp. $144-145$.

3 J. Bentham wrote: 'We shall find that there is no such thing as natural property; it is entirely the creature of law. Property is nothing more than the basis of a certain expectation...', 
In the doctrine of law there were framed numerous notions of ownership right, emphasising different aspects (features) of this institution. In the $19^{\text {th }}$ century F.C. v. Savigny defined property right as 'unlimited and exclusive power of a person over a thing's. B. Windscheid, however, emphasising the dominant role of an owner, accepted the fact that the property right, precisely: the owner's power, may be limited by statutory restrictions established in favour of other entities (private or public) ${ }^{5}$. G. Hartmann emphasised even more that the property right as a right is assigned to particular entities within a community; thus it can result in limitations introduced by the community and in its favour ${ }^{6}$. The Czech civil lawyer of the interwar period, Antonin Randa ${ }^{7}$, stressed out that the property right means a legal power of 'direct and non-limited dealing with a thing'. The Polish civil lawyer, A. Stelmachowski, emphasised that in fact such a power is not unlimited; as it is a part of a legal system which protects it and at the same time defines its frames ${ }^{8}$.

On the basis of Article 544 of the Napoleonic Code (widely considered as the first modern codification of laws, which defined the property right in accordance with ideas of the Enlightenment" property is the right of enjoying and disposing of things in the most absolute manner, provided they are not used in a way prohibited by the laws or statutes' ${ }^{10}$. This approach emphasised on the one hand priority given to the owner's rights, on the other hand however it accepted the possibility of statutory (or systemic) limitations of enjoying such rights. Those limitations could have been introduced, in accordance

J. Bentham, Theory of Legislation, Vol. 1, p. 145.

4 F.C. v. Savigny, System des heutigen Römischen Rechts, Bd I, p. 367.

5 B. Windscheid, Th. Kipp, Lehrbuch de Pandektenrechts, Band I, ed. 9, pp. 856-861.

6 G. Hartmann, Rechte an eigener Sache. "Untersuchungen zur Lehre von Eigentrecht" 1879, Vol. 17, pp. 130-131.

7 A. Randa, Právo vlastnicke dla nakovského práva v systematyckém porádku, Praha 1922, pp. 1-3.

8 A. Stelmachowski, [In:] System Prawa Prywatnego, $2^{\text {nd }}$ ed., Vol. 3, ed. T. Dybowski, Warszawa 2007, p. 229.

9 K.Zaradkiewicz, Instytucjonalizacja wolności majątkowej(Koncepcja prawa podstawowego własności i jej urzeczywistnienie w prawie prywatnym), Warszawa 2013, p. 38.

10 Translation by E. Buczalski, Kodeksy cywilne obowiazujace na Ziemiach Centralnych Polski włącznie z Kodeksem zobowiązań, Warszawa 1936, p. 310. 
with dominating in the $18^{\text {th }}$ and $19^{\text {th }}$ centuries Roman theory of property right, only 'in points' and only by explicit statutory rules ${ }^{11}$.

Starting with the 1850s. the idea of unlimited scope of the ownership rights (taken from the Roman law) was superseded by the idea of a 'relatively absolute' right. It was the German civil code of 1896 which stated in $\$ 903$ that 'the owner of a thing may, to the extent that a statute or third-party rights do not conflict with this, deal with the thing at his discretion'. The Italian civil code of 1942 empowered the owner to use as well as dispose of a thing at their discretion, nevertheless - in accordance with obligations resulting to the owner from the legal order. The code of the Kingdom of the Netherlands of 1992 provided that the owner has the right to use a thing with the exclusion of other persons; he/she cannot however violate rights of other persons, limitations provided by a statute, as well as customary law (Art. 5:1,2 of the civil code of the Netherlands).

So-called German concept of the ownership right, adopted in Europe in the $20^{\text {th }}$ century, provides for that the ownership right is not unlimited; the legal order encompasses frames outside which the power (a set of an owner's powers) of an owner is not protected by the law ${ }^{12}$. There should be at the same time a distinction made - what was emphasised by Jan Wasilkowski in 1963 - between 'restrictions of the exclusiveness scope which results directly from a statute, and limitations resulting from subjective rights of third parties to a thing ${ }^{13}$.

It is symptomatic that the German concept of the property right was not introduced in the expected legislation, i.e. in the German civil code (particularly in $\$ 903$ of the code) $)^{14}$. It is however in Art. 140 of the Polish civil code of 1964. It provides for that 'within the limits specified by statute and the principles of community coexistence the owner may, to the exclusion of other persons, use the thing in conformity with the social and economic purpose of his right, in particular he may collect profits and other proceeds from the thing.

11 See: Z. Kędzia, Geneza praw człowieka i obywatela, [In:] Prawa i obowiązki obywateli. Wybór źródeł. Wrocław-Warszawa-Kraków-Gdańsk 1978.

12 A. Wasilewski, Administracja wobec prawa własności nieruchomości gruntowych. Rozważania z zakresu prawa administracyjnego, "Zeszyty Naukowe UJ. Prace Prawnicze” 1972, Vol. 54.

13 J. Wasilkowski, Zarys prawa rzeczowego, Warszawa 1963, p. 74.

14 A. Wasilewski, Administracja wobec własności..., p. 17. 
He may dispose of the thing within the same limits' ${ }^{\prime 15}$. Thereby the property right is shaped by statutory defined legal order; an additional determinant of the scope and mean of using a thing are (quite generally defined) principles of community coexistence.

II.

Constitution of the Republic of Poland of $2^{\text {nd }}$ April 1997 at least three times deals with ownership (property right). Firstly, it refers to ownership in Chapter I 'The Republic' which concerns basic principles of the state. Article 21 should be considered as a systemic guarantee. The Constitution provides for that 'The Republic of Poland shall protect ownership and the right of succession' (point 1), and 'Expropriation may be allowed solely for public purposes and for just compensation' (point 2). By such regulation the constitutional legislator guarantees protection of property right (its integrity) and at the same time allows the possibility to take it away (expropriation). As well the constitutional legislator limits such possibility to cases related to public purpose, to which - in such cases - priority is given before the protection of property. Furthermore, it provides the obligation to pay 'just compensation' to the expropriated person ${ }^{16}$.

Secondly, Polish constitution refers to 'the right to ownership' in Art. 64 points 1-3 in Chapter II, regarding 'The Freedoms, Rights and Obligations of Person and Citizens', which guarantees constitutional status and protection of the 'right to ownership'. Relevant regulation can be found in subchapter 'Economic, Social and Cultural Freedoms and Rights' and it is placed at the beginning of regulations in the aforementioned subchapter, what indicates the intention of providing this regulation with vital importance within the abovementioned group of freedoms and rights.

15 The criterion of principles of community coexistence for the first time appeared in works on the Polish civil code draft in 1957. See: K. Zaradkiewicz, Instytucjonalizacja wolności majatkowej..., p. 44, footnote 210 .

16 It can be assumes that the purpose of a compensation is preservation of property economic value in the expropriated person's assets, with the change of its form (but preserving its value). See: T. Woś, Wywtaszczenie nieruchomości i ich zwrot, $5^{\text {th }}$ ed., Warszawa 2011, p. 43. 
In Art. 64 of the Constitution of the Republic of Poland, which consists of three parts, the most important are, from the point of view of the constitutional status of 'the right to ownership', points 1 and 3 of Art. 64. Article 64 point 1 guarantees to everyone (grants on an abstract level) 'the right to ownership', other property rights and, what's more - the right of succession. Article 64 point 3 refers to crucial - from the point of view of correlation: private law-public law - question of constitutional conditions for acceptability for ownership limitations. This regulation provides particularly for that the right to ownership may only be limited by means of a statute and only to the extent that it (i.e. the statute) does not violate 'the substance of the right'.

The aforementioned regulation involves three remarks. Firstly, the Constitution allows execution of ownership (the right to ownership) limitations. Secondly, it introduces an absolute formal requirement that possible limitation be executed by means of a statute (i.e. on the basis of a general normative act issued by the legislative power). Furthermore, the constitutional lawmaker requires that the scope of limitations executed by means of a statute does not reach a sphere which is considered by the constitutional lawmaker as 'the substance of the property' (its core).

Incidentally to those remarks comes a reflection, that the constitutional lawmaker provided the public authorities, precisely speaking - the legislative power (the Sejm and the Senate) together with the authority of executive power (which is the President of the Republic of Poland), with a constitutional authorisation to (possible) determination of ownership limitations (let keep to the literal wording of Art. 64 point 3 of the Constitution). It depends on these authorities whether statutory limitations of ownership will be introduced, as well as what will be their scope and character. The limit to the discretionary powers, which results ex lege fundamentale is the constitutional prohibition of violating the substance of ownership (the notion was not defined by the constitutional lawmaker) ${ }^{17}$.

The characteristic feature of statutory limitations of ownership is that they shall remain in the present legal order. Their elimination or expiration results in the fact that ownership returns to its previous extent, and the owner

17 According to K. Zaradkiewicz, and this view should be agreed to, the substance of the constitutional ownership right involves its exclusiveness (within the scope of using a thing or other object of property), as well as unlimited duration of the owner' rights. 
recovers the possibility of executing their authority as the owner within the scope which was previously unavailable. This is the consequence of the principle of entireness and absolute nature of the ownership right (Absolutheit).

The Polish civil code does not directly indicate the owner's discretion in executing their prerogatives. Neither does it make a distinction between the freedom of disposing a thing (or other object of property) and the owner's exclusiveness, which is characteristic of other codifications.

Walerian Pańko emphasised in his works that the owner's exclusiveness ${ }^{18}$ shall not be considered as total nowadays; participation of other entities (including public authorities) is possible in executing owner's rights towards property (or other objects, including those of intangible character, of the property right).

\section{III.}

Constitutions of contemporary states, by providing guarantees of property protection to private entities (also: other entities), in the first place secure the durability of this property right as a constitutional (basic) right of individu$\mathrm{als}^{19}$. Particularly, the aim is to keep the existing legal status.

The constitutional guarantee, as well as on a statutory level - a guarantee provided by the civil law (the civil code), involves all partial rights resulting from the ownership, and aiming at their execution prerogatives of the owner ${ }^{20}$. The Constitution as well as statutes protect the present status of matters. Polish Constitutional Tribunal related this guarantee

18 This exclusiveness (which is characteristic of ownership and other absolute rights) involves: a) in general - unlawfulness of intervention of third parties within the scope of protected subjective ownership right, b) third parties do not have any influence on disposing a given tangible or intangible asset, c) granting the owner legal claim in order to protect property before factual violation (including those made by public authority). See: W. Pańko, O prawie własności I jego współczesnych funkcjach, Katowice 1984, pp. 14-16.

19 It is therefore a guarantee of a certain status of an individual's right (Rechtsstellungsgarantie, Individualrechtsgarantie). See also rulings of the Polish Constitutional Tribunal: ruling of $15^{\text {th }}$ December 2004, K2/04 (OTKZU Nr 11/A/2004, poz. 17) and ruling of $10^{\text {th }}$ July 2012, P 15/12 (OTKZU Nr 7/A/2012, poz. 77).

20 K. Zaradkiewicz, op.cit., p. 222 (with references to judicature of the German Federal Constitutional Court). 
to the rule of protection of acquired rights. The aforementioned rule involves prohibition of depriving individuals (citizens) of subjective rights (and their prospects), as well as restricting those rights to the extent where the substance of the right is violated. The legislator is entitled to limit the acquired right, however on two fundamental conditions. Firstly, limitation cannot involve - in the case of the property right - depravation of prerogatives which constitute the substance of the right. Secondly, limitation of the property right may be introduced only to the extent which is necessary (i.e. obeying the principle of proportionality) for the reason of significant public interest, with full compensation (equivalence) of lost profits $^{21}$. The concept of expropriation is a deviation from guarantee of the permanent character of the property right; the guarantee of its durability is replaced by the guarantee of its value. Nevertheless, when a significant public purpose, because of which the property was taken from the owner (expropriation), proves to be no longer in effect, the guarantee of durability of the property right comes to its place $^{22}$. According to judicature of Polish Constitutional Tribunal, in such conditions the expropriated real estate should be given back ${ }^{23}$. Referring to Art. 21 point 2 of the Constitution of the Republic of Poland of 1997 the Constitutional Tribunal adjudicated that 'if ... a public purpose for which a real property was expropriated is not executed or the expropriated real estate is not necessary to this public purpose, then there is neither constitutional legitimacy of an intervention in a private property, nor legal basis (reason) for acquisition of the property right by a public entity'24.

\footnotetext{
21 See rulling of Polish Constitutional Tribunal of $30^{\text {th }}$ November 1988, K 1/88.

22 See in German literature, e.g.: H.I.Papir, [In:] Grundgesetz. Komentar, Band II, eds. Th. Maunz, G. Dürig, München 2010, pp. 23-24, in Polish literature: K. Zaradkiewicz, Instytucjonalne ..., pp. 226-227.

23 See, e.g. rulings of the Constitutional Tribunal of $3^{\text {rd }}$ April 2008, K6/05 and of $24^{\text {th }}$ October 2001, 3K/01.

24 At the same time (in the judgement of $13^{\text {th }}$ December 2012, P 12/11) the Constitutional Tribunal made a reservation that 'Article 21 point 2 of the Constitution shall not be considered as a basis for a constitutional right for restitution of real estates which were expropriated in a procedure which met constitutional standard set for expropriation'. The above concerned the case in which the primary public purpose of expropriation was replaced by another public purpose. See as well T. Woś, Wywłaszczenie..., pp. 62-63.
} 
The motive of statutory limitations of the ownership right (which cause that the property right is not of an absolute character, notwithstanding its durability and the scope of the owner's prerogatives) is the general interest: protection of a welfare of all the citizens or a numerous group of citizens (e.g. a territorial community $)^{25}$.

A typical kind of limitations of the ownership right to real estates, which are motivated by questions related to public social interest, are limitations introduced by statutes which concern spatial planning and construction $\mathrm{law}^{26}$. Another group of statutory provisions concerns natural environment protection. In the Constitution of the Republic of Poland the admissibility of statutory limitations in exercising the owner's prerogatives (meaning: the ownership right) is confirmed in Art. 31 point 3 of the Constitution [which belongs to general provisions of chapter II (The Freedoms, Rights and Obligations of Persons and Citizens)]. Furthermore, Art. 64 point 3 of the Constitution confirms a possibility of introducing such a restriction (caused by a public interest) towards the property right. The substance of accepted restrictions, within frames of Art. 31 point 3, is exclusion of execution of some owner's rights and (or) limitation of their scope. On the background of Polish constitutional provisions, i.e. Art. 31 point 3 (which defines general premises and limits of that statutory restrictions in exercising constitutional freedoms and rights) and Art. 64 point 3 of the Constitution (which allows the possibility of freedoms limitation by means of statutes), an interpretation controversy arose. A question was asked: does Art. 64 point 3 as lex specialis exclude the application of legi generali, i.e. Art. 31 point 3 ?

When ruling on that matter, Polish Constitutional Tribunal (consequently from 1999 to the present times) adopted the position that Art. 31 point 3 should be applied regardless of Art. 64 point 3 . Those provisions do not mutually exclude themselves, particularly because of the fact that Art. 64 point 3 does not indicate a catalogue of constitutional values, attainment of which justifies the limitation of exercising ownership rights. Article 64 point 3 limits itself to: a) indication of a statutory form of ownership limitations; b) statement that the

25 See ruling of Polish Constitutional Tribunal of $28^{\text {th }}$ May 1991, K 1/91 (OTK 1991, poz. 4).

26 Judgement of Polish Constitutional Tribunal of $7^{\text {th }}$ February 2001, K 27/00 (OTK ZU Nr 2/2001, poz. 29). 
abovementioned limitations cannot be of an excessive character, particularly that they shall not violate (destroy) the substance of the ownership right ${ }^{27}$.

Article 31 point 3, as lex generalis (a provision which refers to all constitutional freedoms and rights), indicate two additional obligatory requirements for the possibility of ownership limitations. It specifies constitutional values (directly related to a public interest: the state's safety, public order, environment protection, health care, and public morality protection), within the scope of which, as well as for protection of which limitations of constitutional rights, including the property right, can be introduced. Co-application of Art. 31 point 3 (which is generally motivated by protection of a society's interest) and Art. 64 point 3 (which correlates with the constitutional guarantee of ownership and other property rights, as well as their protection) constitutes an example of interference of public law and private law elements (considering prevailing quantitatively and functionally 'set' of civil law claims aiming at ownership right protection) ${ }^{28}$.

\section{Literature}

Bentham J., Theory of Legislation, Vol. 1, Boston 1840.

Garlicki L., Przesłanki ograniczania konstytucyjnych praw i wolności (na tle orzecznictwa Trybunału Konstytucyjnego), "Państwo i Prawo" 2001, Issue 10.

Hartmann G., Rechte an eigener Sache. "Untersuchungen zur Lehre von Eigentrecht" 1879, Vol. 17.

Kaczmarczyk M., Wstęp do socjologicznej teorii własności, Warszawa 2006.

Kędzia Z., Geneza praw człowieka i obywatela, [In:] Prawa i obowiazki obywateli. Wybór źródeł, Wrocław-Warszawa-Kraków-Gdańsk 1978.

27 See rulings of Polish Constitutional Tribunal, e.g.: of $22^{\text {nd }}$ February 1999, K23/98 (OTK ZU Nr 2/1999, poz. 25; of $16^{\text {th }}$ October 2007, K 28/06 (OTK ZU Nr 9/A/2007, poz. 104; $18^{\text {th }}$ March 2010, K 8/08 (OTKZU Nr 3/A/2010, poz. 23).

28 See M. Wyrzykowski, Granice praw i wolności - granice władzy, [In:] Obywatel - jego wolności i prawa, ed. B. Oliwa-Radzikowska, Warszawa 1998, pp. 52-54; L. Garlicki, Przestanki ograniczania konstytucyjnych praw i wolności (na tle orzecznictwa Trybunału Konstytucyjnego), "Państwo i Prawo" 2001, Issue 10, pp. 7-8. Regardless, it is worth mentioning that also the premise of 'protection of freedoms and rights of other persons' (prima facie: aiming at individual interest protection) which can be noticed e.g. in so called neighbouring law, similarly aims at ensuring consonant community coexistence, which is related to public interest. 
Kodeksy cywilne obowiązujace na Ziemiach Centralnych Polski włącznie z Kodeksem zobowiqzań, trans. E. Buczalski, Warszawa 1936.

Lehmann J., Schherschaft und Socialbindung, Berlin 2004.

Lorenz K., Volf M., Allgemeiner Teil des bürgerlichenRechts, $9^{\text {th }}$ edition, München 2004. Pańko W., O prawie własności I jego wspótczesnych funkcjach, Katowice 1984.

Pańko W., Własność jako kategoria ekonomiczna a prawo własności, Acta Universitatis Wratislaviensis, No. 609, Prawo, Wrocław 1983.

Papir H.I., [In:] Grundgesetz. Komentar, Band II, eds. Th. Maunz, G. Dürig, München 2010. Radbruch G., Filozofia prawa, Warszawa 2009.

Randa A., Právo vlastnicke dla nakovského práva v systematyckém porádku, Praha 1922. Stelmachowski A., [In:] System Prawa Prywatnego, $2^{\text {nd }}$ ed., Vol. 3, ed. T. Dybowski, Warszawa 2007.

Wasilewski A., Administracja wobec prawa własności nieruchomości gruntowych. Rozważania z zakresu prawa administracyjnego, "Zeszyty Naukowe UJ. Prace Prawnicze" 1972, Vol. 54.

Wasilkowski J., Zarys prawa rzeczowego, Warszawa 1963.

Windscheid B., Kipp Th., Lehrbuch de Pandektenrechts, Band I, ed. 9.

Woś T., Wywłaszczenie nieruchomości i ich zwrot, $5^{\text {th }}$ ed., Warszawa 2011.

Wyrzykowski M., Granice praw i wolności - granice władzy, [In:] Obywatel - jego wolności i prawa, ed. B. Oliwa-Radzikowska, Warszawa 1998.

Zaradkiewicz K., Instytucjonalizacja wolności majątkowej(Koncepcja prawa podstawowego własności i jej urzeczywistnienie w prawie prywatnym), Warszawa 2013. 